\title{
ФАКТОРЫ, ВЛИЯЮЩИЕ НА ВОЗРАСТ ПОЛОВОГО РАЗВИТИЯ ПО ДАННЫМ ПРОСПЕКТИВНОГО КОГОРТНОГО ИССЛЕДОВАНИЯ RUSSIAN CHILDREN'S STUDY
}

\author{
1,2Сергеев О.В., ${ }^{3}$ Бернс Д.С., ${ }^{3}$ Коррик С.А., ${ }^{1,2}$ Диков Ю.Ю., ${ }^{1,2}$ Денисова Т.А., ${ }^{4}$ Ревич Б.А., ${ }^{5}$ Ли \\ М.М., ${ }^{3}$ Хаузер Р., ${ }^{3}$ Виллиамс П.Л., от имени команды «Russian Children's Study»
}

\author{
${ }^{1}$ Научно-исследовательский институт физико-химической биологии имени А.Н. Белозерского МГУ, \\ Москва, Россия \\ ${ }^{2}$ ЧГОО Ассоциация медицинских работников г.Чапаевска, Чапаевск, Россия \\ ${ }^{3}$ Гарвардская школа общественного здоровья им. Чан, Бостон, США \\ ${ }^{4}$ ФБУН Институт народнохозяйственного прогнозирования РАН, Москва, Россия \\ ${ }^{5}$ Медицинский колледж Сидней Киммел, Джефферсон Университет, Филадельфия, США
}

Цель. Изучить факторы, влияющие на возраст наступления признаков начала полового развития (НПР) и полового созревания (ПС) в проспективной когорте мальчиков, представляющих субпопуляцию одного российского города, наблюдающихся с 8 до 20 лет и старше (Российское исследование детского здоровья, Russian Children's Study).

Дизайн/Методы. В 2003-2005 гг 516 мальчиков 8-9 лет, проживающих в городе Чапаевск, Самарская область, были включены в когорту (первичный отклик 86\%). В течение 13 лет проводилось ежегодное наблюдение показателей роста, полового и физического развития участников когорты, преимущественно в их месяц рождения. Отклик участия в исследовании на протяжении всего периода оставался высоким, >64\% в возрасте 18 лет. Половое развитие (ПР) оценивалось по трем показателям, включая стадии развития гениталий (Г1-Г5) и лобкового оволосения (П1-П5) по Таннеру и объем яичек, измеренный с помощью орхидометра. НПР регистрировалось при наступлении 2-й стадии развития гениталий (Г2), 2-й стадии лобкового оволосения (П2), а также при объеме одного из яичек более 3 мл (ОЯ). ПС регистрировалось при Г5, П5, а также при ОЯ >=20мл. Возраст наступления того или иного события ПР рассчитывался как срединная точка между возрастом, во время которого было диагностировано появление признака, и возрастом в момент предыдущего обследования. Из статистического анализа были исключены мальчики с тяжелыми хроническими заболеваниями $(\mathrm{n}=10)$, сироты $(\mathrm{n}=17)$ и мальчики, у которых отсутствовала информация по сопутствующим факторамковариатам $(\mathrm{n}=8)$.

Результаты. Среди 481 мальчика средний возраст (95\% доверительный интервал, ДИ) НПР, стандартизированный на ковариаты, составил 9,5 лет $(9,3-9,6)$ по Г2, 11,8 лет $(11,6-11,9)$ по П2 и 10,4 лет (10,2-10,5) по ОЯ>3мл. Средний возраст (95\% ДИ) ПС составил 14,7 лет $(14,6-14,8)$ по Г5, 16,1 лет $(16,0-16,3)$ по П5 и 13,9 лет $(13,8-14,0)$ по ОЯ>=20мл. Более высокое потребление калорий было связано с ранним возрастом наступления Г5. Низкий семейный доход, низкое образование родителей, отсутствие биологического отца в семье, молодой возраст матери, более высокий уровень свинца в крови в 8-9 лет (>5 мкг/дл) были связаны с более поздним возрастом наступления ПС. Повышенный вес при рождении был связан с более ранним возрастом наступления ПС, оцененному по ОЯ. Позднее наступление у матери менархе было связано с более поздним возрастом ПС по всем трем половым признакам. Похожие взаимосвязи наблюдались для рассматриваемых признаков с возрастом НПР. Возраст наступления ПС по стадии развития гениталий (Г5), 14,7 лет, был сравним с возрастом ПС в других проспективных когортах, 14,3-14,9 лет (Roche et al., 1995; Susman et al., 2010) и в поперечных исследованиях, 14,5-15,9 лет (Willers et al., 1996; Herman-Giddens et al., 2001; Juul et al., 2006; Papadimitriou et al., 2011; Herman-Giddens et al., 2012). 
Выводы. В уникальной проспективной когорте оценены возраст начала полового развития и полового созревания, а также социо-демографические и факторы окружающей среды, влияющие на наступление признаков пубертата и половой зрелости.

Поддержка: грант NIH, CШA, \#\#R01ES0014370.

Ключевые слова: пубертат; когортное исследование; объем яичек; половое развитие; половое созревание; стадии по Таннеру 